\title{
Abstracts
}

\section{Celebrating the Critique's Fiftieth Anniversary}

Ronald Aronson

AbsTRACT: When published, Sartre's Critique of Dialectical Reason appeared to be a major intellectual and political event, no less than a Kantian effort to found Marxism, with far-reaching theoretical and political consequences. Claude Levi-Strauss devoted a course to studying it, and debated Sartre's main points in The Savage Mind; Andre Gorz devoted a major article to explaining its importance and key concepts in New Left Review. Many analysts of the May, 1968 events in Paris claimed that they were anticipated by the Critique. But the book has had a very quiet 50th anniversary: it is now clear that the project has had little lasting effect beyond a narrow band of specialists. It has not entered the wider culture, has not been picked up beyond Sartre scholars except by one or two philosophically interested social scientists and feminist thinkers; and after the energy of 1968 wore off the Critique faded as well from the radar of political activists. This article asks and attempts to answer the perplexing question: Why? What became of the great promise of Sartre's project?

KEYwORDs: Bolshevik Revolution, deviation, Marxism, practicoinert, praxis, socialism

\section{Sartre, Foucault and the Critique of (Dialectical) Reason}

Thomas R. Flynn

Aвstract: "Dialectical" stands in parentheses because I wish to discuss both authors in terms of a critique of reason as such in addition to specifying the issue in terms of their respective assessments of the dialectic. But I shall first consider how each employs the term "critique." So my remarks will focus on Critique, Reason and Dialectic in that order. Of course, each topic understandably bleeds into the others. In view of the occasion, I shall conclude with a brief sketch of 
four milestones along Sartre's way from Being and Nothingness to the Critique.

KEYwORDS: archaeology, humanism, necessity (dialectical), neurosis of dialectic, practico-inert, reason (analytic, synthetic)

\section{Fanon's The Wretched of the Earth as the Fulfillment of Sartre's Critique of Dialectical Reason}

Robert Bernasconi

Frantz Fanon was an enthusiastic reader of Sartre's Critique of Dialectical Reason and in this essay I focus on what can be gleaned from The Wretched of the Earth about how he read it. I argue that the reputation among Sartre's critics of the Critique as a failure on the grounds that it was left incomplete should take into account its presence in Fanon's The Wretched of the Earth. Their shared perspectives on the systemic character of racism and colonialism, on the genesis and fragility of groups, and on parties indicates the vitality of the ideas set out in the Critique. However, these similarities between the two thinkers are offset by their differences on national consciousness and on the rural masses. I end by speculating about a certain defence on Sartre's part toward Fanon's concrete experience.

KEYwORDs: colonialism, Frantz Fanon, groups, national consciousness, racism, violence

\section{Sartre's Integrative Method: Description, Dialectics, and Praxis}

Matthew C. Ally

ABSTRACT: This essay revisits the question of Sartre's method with particular emphasis on the posthumously published Notebooks for an Ethics, Critique of Dialectical Reason (Volume II), and "Morale et histoire." I argue that Sartre's method-an ever-evolving though never seamless blend of phenomenological description, dialectical analysis, and logical inference-is at once the seed and fruit of his mature ontology of praxis. Free organic praxis, what Sartre more than once calls "the human act," is neither closed nor integral, but is rather intrinsically open-ended and integrative. Thus a philosophical method that seeks at once to illuminate human experience and 
human history must itself be both a reflection and inflection of the essential openness and integrativity of praxis itself. In the conclusion, I argue that the openness and integrativity of Sartre's method are its core strengths and the sources of its continued philosophical worth.

KEYwORDs: dialectics, integrative inquiry, method, phenomenology, praxis, Sartre 